\author{
Maciej P. Denkowski \\ ORCID 0000-0001-7231-2482 \\ Jagiellonian University, Faculty of Mathematics and Computer Science, \\ Institute of Mathematics \\ (Kraków, Poland) \\ maciej.denkowski@uj.edu.pl
}

\title{
Leonhardi Euleri Opera Omnia \\ IVA/7: Commercium Epistolicum \\ (Euler - French speaking scientists from \\ Switzerland). Editors: S. Bodenmann, \\ V. Hug, M. Ilić, A. Kleinert. \\ Basel: Birkhäuser, 2017, XII+621 pages - \\ A volume overview
}

\begin{abstract}
We give an overview of the seventh volume of series IVA of the Birkhäuser edition of Leonhard Euler's complete works and correspondence. This volume contains Euler's correspondence in French with ten of his Swiss countrymen: Louis Bertrand, Charles Bonnet, Marc-Michel Bousquet, Jean de Castillon,
\end{abstract}

\begin{tabular}{|c|c|c|c|c|c|}
\hline \multicolumn{2}{|c|}{$\begin{array}{l}\text { PUBLICATION } \\
\text { INFO }\end{array}$} & $\begin{array}{c}\text { Pistoriae } \\
\text { cientiarum }\end{array}$ & $\begin{array}{r}\text { e-ISSN 2543-702X } \\
\text { ISSN 2451-3202 }\end{array}$ & 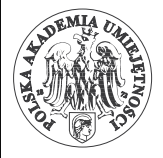 & $\underset{\substack{\text { DIAMOND } \\
\text { OPEN ACCESS }}}{2}$ \\
\hline \multicolumn{6}{|c|}{$\begin{array}{l}\text { CITATION } \\
\text { Denkowski, Maciej P. 2020: Leonhardi Euleri Opera Omnia IVA/7: Commercium Epistolicum (2017, Euler- } \\
\text { French Speaking Scientists From Switzerland). Editors: S. Bodenmann, V. Hug, M. llić, A. Kleinert. Basel: } \\
\text { Birkhäuser, 2017, XII+621 pages - A volume overview. Studia Historiae Scientiarum 19, pp. 545-560. } \\
\text { DOI: } 10.4467 / 2543702 X S H S .20 .017 .12573 .\end{array}$} \\
\hline \multicolumn{3}{|c|}{$\begin{array}{l}\text { RECEIVED: } 13.06 .2020 \\
\text { ACCEPTED: } 22.08 .2020 \\
\text { PUBLISHED ONLINE: } 30.09 .2020\end{array}$} & $\begin{array}{c}\text { ARCHIVE } \\
\text { POLICY } \\
\text { Green SHERPA / } \\
\text { RoMEO Colour }\end{array}$ & 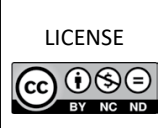 & Crossref \\
\hline WWW & \multicolumn{5}{|c|}{ https://ojs.ejournals.eu/SHS/; http://pau.krakow.pl/Studia-Historiae-Scientiarum/archiwum } \\
\hline
\end{tabular}


Gabriel Cramer, Philibert Cramer, Gaspard Cuentz, Albrecht von Haller, Georges-Louis Lesage and Johan Caspar Wettstein. A letter of the German Johann Michael von Loën to Euler, mentioned in the Euler-Bertrand letter exchange is also included as well as the recently rediscovered first letter of Euler to Jean le Rond d'Alembert in supplement. The letters cover a large range of topics also outside Euler's mathematical and physical interests giving a new insight into his non-scientific activities, and thus casting also a new light on this great scientist as a person.

Keywords: Leonhard Euler (1707-1783), complete works, correspondence in French, Leonhardi Euleri Opera Omnia IVA/7

\title{
Leonhardi Euleri Opera Omnia IVA/7: Commercium Epistolicum (Euler - French speaking scientists from Switzerland). Editors: S. Bodenmann, V. Hug, M. Ilić, A. Kleinert. Basel: Birkhäuser, 2017, XII+621 pages - Omówienie tomu
}

\begin{abstract}
Abstrakt
Niniejsze opracowanie poświęcone jest omówieniu siódmego tomu serii IVA dzieł zebranych Leonarda Eulera wydanego przez oficynę Birkhaeuser. Tom ten zawiera korespondencję Eulera w języku francuskim adresowaną do dziesięciu jego szwajcarskich rodaków: Ludwika Bertranda, Karola Bonneta, Marka-Michała Bousqueta, Jana de Castillon, Gabriela Cramera, Filiberta Cramera, Kacpra Cuentza, Alberta von Hallera, Jerzego-Ludwika Lesage'a i Jana Kacpra Wettsteina. Dodatkowo uwzględniono w nim list Niemca Jana Michała von Loëna, wspomnianego w korespondencji Eulera z Bertrandem, oraz niedawno ponownie odkryty pierwszy list Eulera do Jana Le Rond d'Alemberta. Listy mają szeroki zakres tematyczny wybiegający poza zainteresowania matematyczno-fizyczne Eulera, dając tym samym nowy wgląd w pozanaukowe życie tego ostatniego i rzucając nowe światło na sylwetkę tego wielkiego naukowca.

Słowa kluczowe: Leonard Euler (1707-1783), dzieła zebrane, korespondencja po francusku, Leonhardi Euleri Opera Omnia IVA/7
\end{abstract}




\section{Introduction}

Leonhard Euler hardly needs to be presented to anyone as everybody is well-acquainted with his - if not all then at least with the most important - scientific achievements.

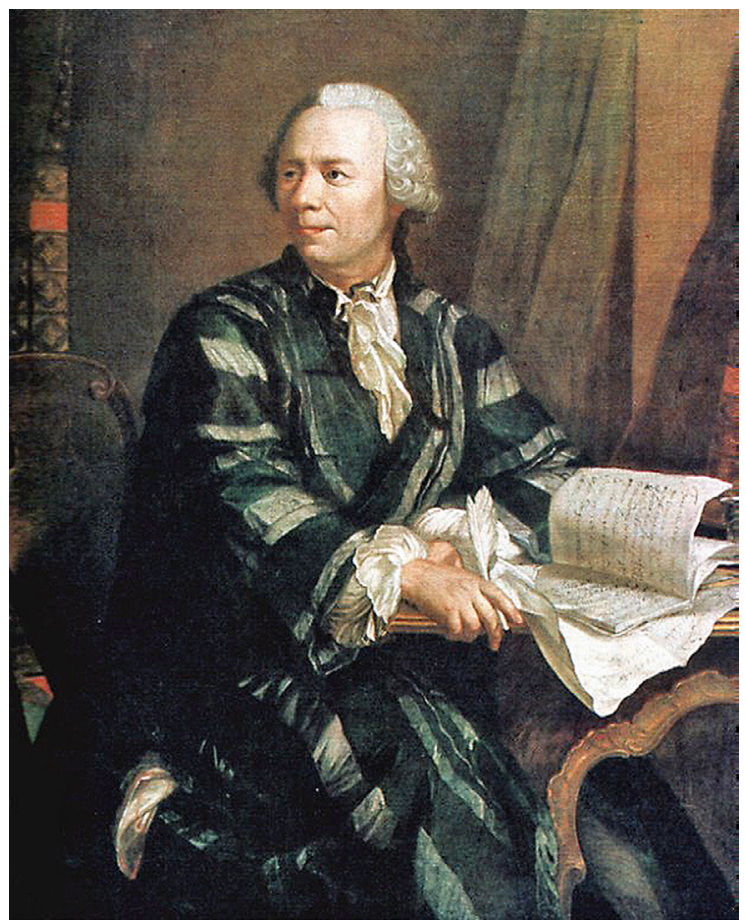

Fig. 1. Leonhard Euler (1707-1783) c. 1756.

Source: Wikipedia (Public Domain).

However, in order to obtain a background on which to display the part of his correspondence we will be dealing with, let us shortly recall that he was born in Basel in 1707 (thus, born a Swiss) to a protestant minister (the faith would play an important role throughout his life), he studied mathematics there with Johann I Bernoulli, but from 1727 he led an expatriated life between St. Petersburg (where he got married), Berlin (1741-1766) and again St. Petersburg, where he died in 1783. He is considered one of the most prolific mathematicians. Once he had left Switzerland, it was never to return there. However, his Swiss identity (not merely Basilian) must have been important to him as he is often 
referred to and himself uses the term of a 'compatriot', e.g. in the letters from Cuentz or Haller and to Wettstein.

The long story of editing Leonhard Euler's complete works (it began in 1907 and it is now almost complete with only two more volumes to be published) is presented in detail in A. Kleinert's article (Kleinert 2015) who is one of the editors of the present volume. Euler's correspondence, the publication of which began in 1967 as series IV, is quite impressive with about 3100 letters written in the $18^{\text {th }}$ century French and German, Latin, of course, and even a few in Russian. Approximately one third of these letters were written by Euler himself dating mostly from his Berlin time. The editors endeavour to regroup the letters chronologically within a given volume (but not in general) and according to the language they were written in. The present volume (Euler 2017) of 621 pages edited by Siegfried Bodenmann, Vanja Hug, Mirjana Ilić and Andreas Kleinert contains letters in French exchanged by Euler almost exclusively with some of his Swiss countrymen, with two exceptions: a letter from the German Johann Michael von Loën and the first letter of Euler to the French mathematician d'Alembert.

In what follows, after a short presentation of the correspondents, I will try to give a general overview of the contents of the letters. As a mathematician I am obviously inclined to pay more attention to the mathematical discussion between Euler and Cramer, or his letter to d'Alembert.

The entire correspondence is truly and beautifully edited: the volume is organized in such a way that each collection of letters is preceded by a short introduction including not only some biographical data of the correspondent and his links to Euler, but also, as it were, a discussion of the letters' content. This should indeed help the reader very much and I am using these introductions to a great extent below, in order not to be tempted to present too many details as a review had better be kept rather short (which is a goal I certainly have not achieved).

\section{The correspondents - who are they?}

There are twelve correspondents. Some are known as scientists with well established fame, some are hardly ever heard of. Keeping the alphabetic order used in the volume, let us list them by adding a few words on each of them and on their correspondence with Euler. 


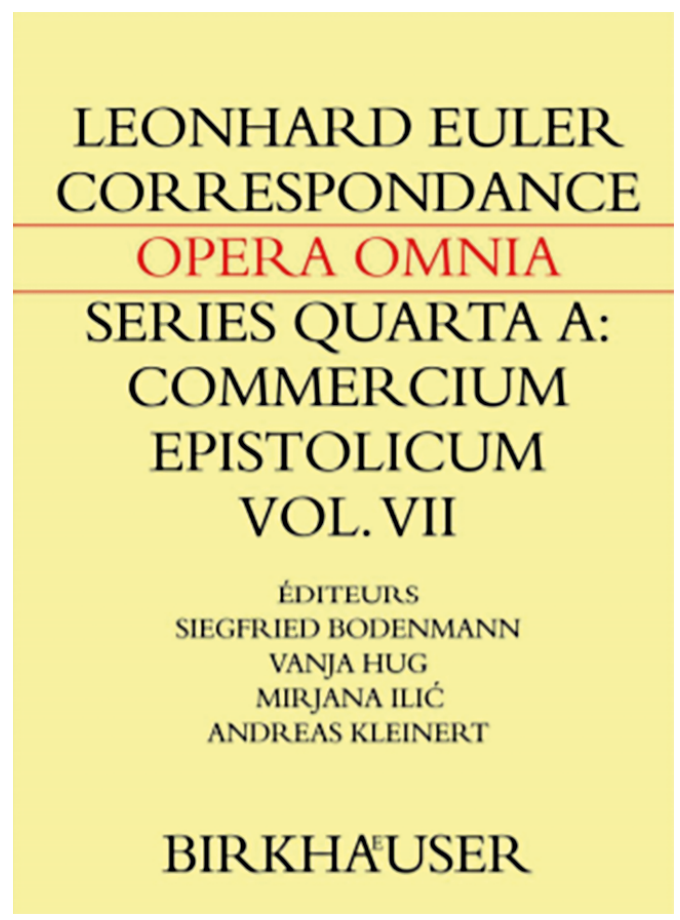

Fig. 2. Leonhardi Euleri Opera Omnia IVA/7 - front page.

There are eleven letters exchanged between Euler and Louis Bertrand between October 1752 and April 1768. Bertrand was much younger than Euler, born in 1731 in Geneva as the youngest son to a French Huguenot refugee and a banker from Montpellier. He studied mathematics with Gabriel Cramer, whose fame was already well established at this time. After Cramer's death, he applied without success for the chair of mathematics at the Academy of Geneva (he was the youngest of the applicants). Assisted by Cramer's cousin Philibert, he moved to Berlin when he worked with Euler among others on the chess-knight problem. Then with Euler's recommendation he makes a journey to England as part of his education. From there he takes charge of several commissions for the sake of Euler and the Berlin Academy. He tries to meet Wettstein, whose health problems make it difficult. After returning to Geneva, he becomes professor of mathematics and physics at the Academy in 1761. It is interesting to note how loyal a disciple Bertrand was: in the introduction to his book Éléments de géométrie (1812) he 
writes clearly that several propositions in plane and spherical geometry that his name was linked to were in fact credited to Euler.

The correspondence with Charles Bonnet was exchanged with some pauses between July 1760 and February 1772. Bonnet was a Genevan naturalist born in 1720, correspondent member of the French Academy of Sciences since 1740, fellow of the Royal Society since 1743. He started writing letters to Euler having an established fame as a scientist. At that moment, his philosophical and religious preoccupations took over his scientific work, mostly due to his eyesight deterioration. He was a close friend of Albrecht von Haller, another correspondent of Euler's and partisan of the preformation theory, i.e. the idea that the organism's development takes place in the progenitor's body and thanks to his soul. Euler, himself a partisan of the epigenesis, vividly opposed Bonnet's ideas.

Marc Michel Bousquet is another Genevan of French Huguenot extraction, born in 1696. A successful editor, he becomes Genevan citizen in 1724. He obtains several regal privileges, from the Holy Roman Emperors Charles VI, Charles VII and Francis I, but also from the Polish king Augustus III (House of Wettin). His publishing house in Lausanne edits works pertaining to mathematics, physics, medicine, sciences, history, philosophy, literature, law, politics, catholic and protestant theology, schoolbooks, prayer books and distributed them across Europe: France, Italy, Spain, Portugal, Germany and the Netherlands. The cost of the beautifully printed books is often higher than the earnings. With some help from the mathematician Gabriel Cramer he published the complete works of Johann I Bernoulli in 1742, which makes him gain some attention from Frederick II of Prussia. This results in the only known letter of Bousquet to Euler, whom he probably was recommended to by Daniel Bernoulli. It contains a copy of king Frederick's short letter to Bousquet and his boasting about it. Bousquet, as we will see in the next section, plays an important role in forming the Swiss correspondence network of Euler.

Jean de Castillon, born Giovanni Salvemini da Castiglione in Florence in 1709, was very gifted in various domains, from mathematics to art. Doctor in law in Pisa (1729), he had to flee Italy after expressing some atheistic views. Once he established himself in Vevey, he opted for the French name of Jean de Castillon and became the Principal of the college in Vevey after gaining notoriety for his Italian translation 
of Alexander Pope's Essay on man. There he also gives private lessons in mathematics and comments upon Newton's Arithmetica Universalis. That is probably why Bousquet offers him the task of editing Newton's Opuscula mathematica, philosophica et philologica with the help of Gabriel Cramer. This cooperation continues and results in Castillon editing Euler's treatise (Euler 1768), which naturally starts their correspondence in 1745 that will continue irregularly until 1765 . Castillon is elected fellow of the Royal Society in 1745 and moves to Lausanne. Three years later, Euler recommends him to Maupertuis, the president of the Berlin Academy, but it takes seven more years for him to become a member of the Academy. In his second letter (there are only six of them, all but one from Castillon to Euler) he reluctantly ponders the possibility of applying for a professorship in St. Petersburg and asks Euler for advice. He chooses Utrecht under the protection of William IV of Orange, whose death results in Castillon finding himself again with no position. He turns again to Euler hoping the latter can help him at the St. Petersburg Academy, but apparently Euler is of no great assistance and finds him too old for a position there. He finally succeeds in obtaining a chair at the Utrecht University. Frederick's II reforms after the Seven Years' War result in Castillon becoming professor of mathematics at the Prussian Artillery School in Berlin in 1763, where he meets Euler. Then a financial affair at the Berlin Academy makes them oppose one another, which is reflected in the letters from this period.

Gabriel Cramer is a very well-known mathematician of German extraction, born in Geneva in 1704. He learned the infinitesimal calculus under the supervision of Johann I Bernoulli in Basel. After a two-year journey across Western Europe (Paris, London, Cambridge, Oxford, Leyden...), he comes back to Geneva where he eventually obtains a chair in mathematics. Among his disciples we find Bertrand, Bonnet or Lesage. Strangely enough, he was not a prolific writer even though he was very popular as a lecturer. He died prematurely in 1752.

A distant cousin of Gabriel Cramer, Philibert Cramer born in 1727, belonged to a long-established family of Genevan printer-booksellers. He was recommended by Gabriel Cramer to Euler when he was still in formation as a printer (later he would become a politician). His correspondence with Euler begins to him with a recommendation to Euler of the young Louis Bertrand. However, in the first letters he does not name him, gauging Euler's disposition. 
There is only one letter from Gaspard (Caspar) Cuentz (born in 1676 in Saint-Gall, first a judge, then a self-taught philosopher and politician, he spent most of his life in Neuchâtel) and it is believed that Euler did not answer his invitation to discuss Cuentz's views 'on the formation, propagation and the nature of the human being'. We can only guess why.

The correspondence with Albrecht von Haller is peculiar: it evolves from a frigid courtesy to almost open enmity (by the standards of that time; it is corroborated by other epistolary sources). Already in the first letter Euler notes that their different scientific interests will make any correspondence difficult. Haller was a naturalist and anatomist born in Bern in 1708. Acting on behalf of the Prussian authorities (Frederick II had a high opinion of Haller), Euler makes a hiring offer to Haller in several letters, who in response brings up some rather exorbitant conditions. When these are turned down, he becomes angry. Haller also plays a role in the contacts between Bonnet, whose views he shares to some extent, and Euler.

Georges-Louis Lesage is another Genevan born in 1724, whose father had fled Burgundy due to religious persecutions. His father introduced him to mathematics, which he studied afterwards under the supervision of Gabriel Cramer. He then turned to medicine and studied in Basel and Paris. Over the years, he acquired international fame and became fellow of the Royal Society and a member of the Paris and Berlin Academies. His scientific interest was concentrated almost exclusively on finding a mechanical explanation for Newton's gravitational force. He tried to do this in terms of streams of tiny unseen particles which he called ultra-mundane corpuscles and which, according to him, impact all material objects from all directions. His correspondence with Euler forms a complete collection consisting of six letters to Euler and three replies from the latter. Lesage's letters are very obsequious. And yet, already from the first reply of Euler it is quite clear that he does not really want to enter the argument. It becomes rapidly apparent that he disapproves of Lesage's ideas, though the letters stay extremely polite. In the seventh letter he admits his error concerning an aether theory but firmly, even vehemently refuses to consider the ultra-mundane corpuscles idea.

The correspondence with Johann Michael von Loën, born in 1694 in Frankfurt am Main to a wealthy family of merchants of Dutch origin, is limited to a single letter to Euler. Von Loën was a distant relative 
of Goethe and Euler. Von Loën's sister was married to the painter Georg Gsell whose daughter Katharina became Euler's wife in 1733. Von Loën was eager to obtain a position in the Prussian administration and that is what the letter is about. As a matter of fact, Euler's influence was such that von Loën eventually got the presidency of Lingen.

Johann Caspar Wettstein born in 1695 in Basel was a pastor and chaplain of first the Dutch then the British ambassador in Paris. With the latter he arrives in England for the first time in 1724. In the service of the earl of Dysart, he completes his scientific formation and makes new acquaintances that ensure his career in England as vicar and preceptor. In 1740-1741 he accompanies the statesman John Carteret's son in a voyage across Europe and meets Euler in St. Petersburg for the first time. Through his journeys Wettstein established a large network of connections. Most of the Swiss visitors to England contacted Wettstein asking for his protection. He became a member of the Berlin Academy in 1752 and fellow of the Royal Society in 1754. The volume presents 56 letters from Euler to Wettstein and one from Wettstein to Euler (all the others are lost), which is the largest collection not only by size but also by the variety of themes.

\section{More on the correspondence}

In brief, the correspondence covers Euler's relations with the network of Swiss scientists and printers-publishers from Romandy: Geneva, Lausanne and Neuchâtel, but also his relations with England, which we see through his exchange with Wettstein. His communications with Haller form a separate category, as well as the one letter from von Loën and the first letter to d'Alembert in supplement. Some of the letters' contents have been discussed in the previous section.

Euler's letter exchange with what we call nowadays Romandy started in 1743 after he was visited in Berlin by the printer and bookseller Marc-Michel Bousquet from Lausanne. The intention of the latter was to gain not only an author whose prints he could sell (and indeed Euler gave him exclusive rights), but also a new partner for the distribution of his prints. As the first book to be printed (Euler 1744) contains many mathematical formulæ requiring the supervision of a skilled mathematician, at Bousquet's suggestion Euler turns to Gabriel Cramer for help. They begin to exchange letters that concern mostly mathematics, 
but on one occasion Cramer also introduces to Euler his young cousin Philibert Cramer, whose journey to Berlin is part of his formation as a printer-bookseller under the auspices of Ambroise Haude, the Berlin Academy official printer.

When Cramer was not available for the second publication (Euler 1748a), Euler and Bousquet contacted Jean de Castillon who had worked with Cramer on Newton's Opuscula mathematica printed by Bousquet. Following the publication, the exchange between Euler and Castillon had not continued for twenty years and was reborn essentially only due to a financial affair at the Berlin Academy concerning partly the selling of almanacs. It resulted in a deterioration of their relationship. In essence, the treasurer Köhler was taking over one fourth of the profits from the almanac sale for himself - and an administrative reform was needed. Castillon was in favour of it, while Euler, fearing any changes would affect the Academy members' income, vehemently opposed any projects and kept rejecting the special commission reports prepared for the king. In the fifth letter Castillon proposes to act as an intermediary between Euler and the commission but is turned down by Euler. Finally, it is Euler who has to withdraw himself, and he eventually leaves Berlin for St. Petersburg while his contacts with Castillon are broken off.

The death of Gabriel Cramer, who was a mentor for Louis Bertrand, makes Philibert Cramer take care of his friend and distant relative. He organizes Bertrand's visit to Euler in Berlin and the first letter of the former dates from 1752 on his way to the Prussian capital, when he met Euler's eldest son Johann Albrecht in Heidelberg. They journeyed together stopping at Johann Michael von Loën, Euler's relative, in Frankfurt am Main. In Berlin Bertrand stays at Euler's home and four years later Euler helps him arrange a visit to England by asking Johann Caspar Wettstein, his London correspondent, to introduce Bertrand to the London scientific community. With his excellent command of English Bertrand returns to Geneva, where he finally obtains the chair in mathematics at the Academy. This leads to new interesting scientific correspondence begun by Georges-Louis Lesage. He congratulates Euler for having his disciple, Bertrand, become professor (as Euler's influence helped in this), but in reality he seeks Euler's approbation for his views on gravity. Euler is not much keen on Lesage's idea of corpuscules ultramondains (ultramundane corpuscles); nonetheless he reads Lesage's communication to the Berlin Academy. 
Another former disciple of Cramer's and both Lesage's and Bertrand's friend, the Genevan naturalist Charles Bonnet, tries to obtain Euler's approval for his studies and probably some help for his aspiration to become a member of the Berlin Academy, which is apparent from the letters. He keeps sending his works to Euler, but Euler clearly neither shares his opinions on preformation theory, nor agrees with his explanation of miracles. It is interesting to see how polite their discussion remains.

Outside this network we have the correspondence with Gaspard (Caspar) Cuentz, an amateur philosopher from Neuchâtel and one letter from Johann Michael von Loën, who would like to see his career in the Prussian administration flourish. In both cases the correspondents sought Euler's protection and advice.

The largest correspondence presented in the volume concerns the exchange with Johann Caspar Wettstein. All the letters but one are from Euler to Wettstein and cover the largest range of topics. They can be divided into three parts. The 'private' topics concern recurrent tobacco orders (Euler must have been a heavy smoker and a connoisseur) and some others like an order for the purchase of geographical maps, or else some recommendation for people visiting England (Euler was clearly eager to help people and often offered his protection). Some contents of the letters can be classified as business, when Euler the academician writes about sending almanacs or making accounts, exchanging mulberry seed between the botanic gardens of Berlin and London, or buying English books for his colleagues from the Berlin Academy. Finally, the third category covers a wide range of scientific matters. Wettstein acts as a spokesman of the English scientific community and an intermediary thereof (in the sixth letter Euler asks James Bradley via Wettstein for his observations on the moon), while Euler gives an account of his recent scientific studies on astronomy or optics or tells about the achievements of other scientists recommending them to their English colleagues. For instance, in the fifth letter he mentions Bering's observations and introduces his remarks on the second Kamchatka expedition by the sentence 'I doubt very much that Russia will ever publish the details of the findings...' It is rather amusing to see Euler's embarrassment expressed in the twelfth letter concerning the communication by Wettstein to the Royal Society of his account of the expedition. He writes explicitly that he sent his apologies to the Academy of St. Petersburg 
lest he be blamed. Starting from 1756, i.e. the beginning of the Seven Years' War we discover Euler as a Prussian patriot founding his sentiments on Christian faith. This does not mean that he sheds his Swiss identity: in letter 49, which starts with his deep concern about the defeat of Kolín and the consequences thereof, he calls Luke Schaub who though Basilian was the British ambassador Wettstein came with to England - our honourable compatriot. Let us mention some other scientific topics covered in these letters: the problem of longitude, the theory of the moon (determining the movement of the moon is complicated by the fact that it is in fact a three-body problem, the moon, the earth and the sun interact; Euler, d'Alembert and Clairaut were particularly interested in the question), the aether theory.

The exchange with Bonnet is also very interesting, when Euler's and Bonnet's opinions diverge, and the two scientists adopt an entirely different style of discussion. Bonnet keeps sending some of his work reminding the rigorous steps he takes in his reasoning, whereas Euler answers with strict and pertinent objections. Even the sympathy that Bonnet expresses towards Euler when he begins to lose his sight (just as Bonnet did), or his attempts to stress their common affection to religion making use of its defense performed by Euler in 1768/1802, cannot create closer ties between the two men. Euler answers by accusing Bonnet of materialism due to his conception of the soul and by making a list of Bonnet's errors in his last letter. Actually, there are two main topics they discussed in the letter. On the one hand, it was the aforementioned preformation theory, which also has a religious flavour and which Euler vehemently opposes with epigenesis. He points out some contradictions in Bonnet's theses (Euler's objections from the 4th letter indicate that he must have read Theoria generationis of Caspar Friedrich Wolff, whom he had a very good opinion of). On the other hand, it was the main assertions from Bonnet's Essai analytique (1760). In the latter, Bonnet builds an analogy between the transmission of sensations and the propagation of light and sound, which leads to several statements on the specificity of sensorial fibres (the specificity of sounds and colours depends on the specialization of the human fibres), which Euler definitely rejects based on his own works and those of Lagrange. Bonnet was strongly influenced by Haller in his views on preformation. In Euler's correspondence with the latter we clearly observe a gradual deterioration in their relationship, which may have also had some impact 
on Euler's contacts with Bonnet. This part of Euler's correspondence is completed by exchanges between Euler's son Johann Albrecht and both Bonnet and Wolff in the supplement.

Finally, let us briefly discuss the correspondence with Gabriel Cramer. As mentioned above, it started when Cramer was in charge of editing Euler's book (Euler 1748a). The beginning was rather slow, even though Cramer mentioned in his first letter that he too worked on some problems treated in Euler's book. Euler expresses his interest in Cramer's work, but Cramer is too occupied to answer this third letter and there is a pause in their exchange. When Euler seeks his help for the edition of his work on algebraic curves, he turns down the offer explaining that he has prepared a similar treatise (Introduction à l'analyse des lignes courbes algébriques, which will appear only in 1750, but as we may infer from the fourth letter in which Cramer gives a long summary of its contents, it was ready as early as 1744) ${ }^{1}$. Even though Cramer hands over Euler's manuscript to Jean de Castillon, he must have read it, as is apparent from the letters 4 to 9 in which he discusses several problems from the treatise. Incidentally, in the fourth letter we find the formulation (discussed later by Euler) of what is now called the Cramer or Cramer-Euler paradox (although Colin MacLaurin was the first to observe it), which Cramer states following a remark 'of some Mr. Braikenridge'. Actually, Cramer makes two statements on cubic curves: firstly, a plane curve of degree three can be determined by nine points; secondly, two such curves can intersect in nine points by Bézout's theorem. The question is how these statements can be true at the same time, as there are at least two distinct cubics passing through a set of nine points, even though nine points supposedly determine a unique cubic. Euler worked on the question for the next couple of years and published his answer in Euler 1748b (we get a preview in his fifth letter; a generalization is Julius Plücker in the $19^{\text {th }}$ century).

Also in the fifth letter Euler introduces the notion of second type cusps (point de rebroussement de la seconde espèce), which will become a central thread of the correspondence. In that letter Euler recalls the discrepancy between l'Hospital and Gua de Malves on the existence of such plane curves' singularities. He admits that he erroneously shared the point

\footnotetext{
1 See Cramer 1750.
} 
of view that such cusps did not exist (and the singularity was in fact reducible) and provides the first known example of a curve having this second type cusp, namely $y^{4}-2 x y^{2}-4 x^{2} y-x^{3}+x^{2}=0$ (it has a form of a bird's beak at the origin). As a matter of fact, in my own research work I once needed such an example and I was unaware of this Euler's equation until I read the correspondence, which shows that we still can learn new things from quite unexpected old sources. Anyway, it took some letters to convince Cramer, who tried only geometric approaches, and the example worked.

Other topics that we come across in this correspondence concern mechanics, astronomy (northern lights, comets), hydrodynamics in the case of rowers, or more abstract notions like logarithms of complex numbers. A concise presentation of the Cramer-Euler exchange can be found in Joffredo 2017. From a mathematical point of view this part of Euler's correspondence would deserve a special treatment and a much larger review. The same can be said of the letter to d'Alembert added at the end of the volume. Its main topic is the problem of vibrating chords and it can be seen as an abstract of Euler's work (Euler 1749) on the subject.

\section{Concluding remarks}

It is very interesting and somehow rewarding to read Euler's French correspondence in the original $18^{\text {th }}$ century French. From a linguistic point of view it does not require special preparation, one easily gets used to the obsolete orthography, but more importantly it is the elegance of the language - typical for those times - mixed with a peculiar, rather open way of expressing one's sentiments that is singularly charming. It forces on the reader a sad reflection about how far the so-called fourth industrial revolution has thrown us away from a deep and understanding exchange of thoughts. I find it rather difficult to imagine a future edition of today's e-mails even of the greatest scientists of our days to be at least half as interesting and pleasurable to read.

From the letters we definitely gain a new portrait of the great scientist. I have known Euler solely for his mathematical achievements; his correspondence shows a man interested in various aspects of natural history, a man that takes care of his friends, a keen observer and polemist, and finally a man of flesh and blood, who has his likes and dislikes. 
I will end my review by stressing once again that the presentation of the volume contents as done by the editors is very helpful for the reader. It contains a thorough discussion of the background of the correspondence in general and for each correspondent separately. The edition of Euler's correspondence certainly demanded much work and it was done brilliantly.

\section{References}

Cramer, Gabriel 1750: L'Introduction à l'analyse des lignes courbes algébriques. Genève: Frères Cramer, Claude Philibert. Available online: https://books.google.pl/ books? id $=$ gtKvSzJPOOAC\&printsec $=$ frontcover.

Euler, Leonard 1744: Methodus inveniendi lineas curvas maximi minimive proprietates gaudentes, sive solutio problematis isoperimetrici latissimo sensu accepti. Lausannæ et Genevæ. Available online: https://books.google.pl/books?id=ZO4tgicf1sAC.

Euler, Leonard 1748a: Introductio in analysin infinitorum, volumes I and II. Lausannæ: Marcum-Michaelem Bousquet. Available online: https://books.google.pl/books?id=jQ4OAAAAQAAJ (vol. I); English translation by Ian Bruce: http://www.17centurymaths.com/contents/introductiontoanalysisvol1.htm.

Euler, Leonard 1748b: Sur une contradiction apparente dans la doctrine des lignes courbes. Mémoires de l'Académie Roy. des sciences et belle-lettres de Berlin, pp. 219-233. Available online: https://scholarlycommons.pacific.edu/cgi/viewcontent.cgi? article $=1146 \&$ context $=$ euler-works. English translation by Sandrah Eckel, Vassar College, 2004. Available online: https://scholarlycommons. pacific.edu $/$ cgi $/$ viewcontent.cgi? filename $=0 \&$ article $=1146 \&$ context $=\mathrm{eu}-$ ler-works\&type $=$ additional.

Euler, Leonard 1749: De vibratione chordarum exercitatio. Nova Acta Eruditorum, pp. 512-527. Available online: http://eulerarchive.maa.org/docs/originals/E119.pdf.

Euler, Leonard 1768/1802: Lettres à une princesse d'Allemagne sur divers sujets de physique et de philosophie. St Pétersbourg. English translation 1802: Available online: https://archive.org/details/letterseulertoa00eulegoog.

Euler, Leonard 2017: Opera omnia IVA/7 — Euler's correspondence with French speaking scientists from Switzerland. Editors: S. Bodenmann, V. Hug, M. Ilic, A. Kleinert. Basel: Birkhäuser, XII+621 pages.

Joffredo, Thierry 2017: "Recherches épineuses" sur les courbes algébriques dans la correspondance entre Leonhard Euler et Gabriel Cramer, conference communication: Présentation du volume 4A/VII de la correspondance de Leonhard Euler. 
Maciej P. Denkowski

Leonhardi Euleri Opera Omnia IVA/7: Commercium Epistolicum...

Bernoulli-Euler Zentrum. Université de Bâle, 17 novembre 2017. Available online: https://halshs.archives-ouvertes.fr/halshs-01638107/file/euler-cramerbale-nov17-joffredo.pdf.

Kleinert, Andreas 2015: Leonhardi Euleri opera omnia: editing the works and correspondence of Leonhard Euler. Prace Komisji Historii Nauki PAU XIV, pp. 13-35. Available online: http://pau.krakow.pl/PKHN-PAU/pkhn-pau-XIV-2015-2.pdf. https://postwarconference.wordpress.com/. 